\title{
EDITORIAL: RAMUS 25
}

\begin{abstract}
latet arbore opaca
aureus et foliis et lento uimine ramus, Iunoni infernae dictus sacer; hunc tegit omnis lucus et obscuris claudunt conuallibus umbrae. sed non ante datur telluris operta subire auricomos quam quis decerpserit arbore fetus. hoc sibi pulchra suum ferri Proserpina munus instituit. primo auulso non deficit alter aureus, et simili frondescit uirga metallo.
\end{abstract}

(Aen. 6.136-44)

Hidden on a dark tree

Is a golden bough - gold its leaves and pliant stemConsecrated to infernal Juno; the whole grove Hides it, enclosed by shadows in the dark valleys. But no one's allowed to enter the earth's secret places Until he's plucked from the tree the golden-haired growth. Fair Proserpina decreed that this be taken to her As tribute. When the first's torn off, a second grows Of gold, and the spray leafs with the same metal.

inde ubi uenere ad fauces graue olentis Auerni, tollunt se celeres liquidumque per aëra lapsae sedibus optatis gemina super arbore sidunt, discolor unde auri per ramos aura refulsit. quale solet siluis brumali frigore uiscum fronde uirere noua, quod non sua seminat arbos, et croceo fetu teretis circumdare truncos, talis erat species auri frondentis opaca ilice, sic leni crepitabat brattea uento. corripit Aeneas extemplo auidusque refringit cunctantem, et uatis portat sub tecta Sibyllae.

(Aen. 6.201-11)

When the doves reached foul-smelling Avernus' throat,

They quickly rose and sliding through the liquid air Settled on the desired place, the twin-natured tree, Where the gold's dishued breath glinted through the branches. As in the woods during winter's cold the mistletoe Blooms with strange leaves, a parasite on its tree, And encircles the round boles with yellow fruit; Such was the sight of leafing gold on the dark Ilex, as foil tinkled in the gentle wind.

Aeneas snatches it at once and rips it off avidly As it resists, and takes it beneath the seer Sibyl's roof.

Ramus was born from these passages and has come of age. It is a moment to celebrate. What follow in this issue are pieces on birthdays, anniversaries and 
other temporal appropriations and uses, which underscore this moment, and function as a celebratory paradigm of the twenty five years of critical activity marked in the journal's pages. Now is also a moment to be aware of debts and indebtedness. Many have worked on behalf of this journal since its birth as an idea in 1970 and its initial realisation in the first months of 1972. Students, colleagues and friends at Monash University, the University of Tasmania, La Trobe Bendigo, Cambridge and USC-too many unfortunately to name, but all known and remembered-have given labour, good will and often passion to this journal's task. We thank them most sincerely. We thank too our panels of referees in the USA, UK, Australia, New Zealand and elsewhere, who in the midst of busy schedules have performed their unpaid, anonymous, self-imposed duties with diligence, generosity and timeliness. We could not exist without them. Nor without our contributors. We take this opportunity to express our deep and enduring appreciation to all who through the deeds of their words have lent support to the objectives of this journal and constituted its critical life. Anniversaries are a time too for reaffirmation or for contemplating disengagement. Perhaps the saddest anniversary reflection in Latin literature is to be found at the conclusion of Fasti 6, where Ovid's narrator, about to celebrate the festival of Fors Fortuna, grimly comments:

Tempora labuntur tacitisque senescimus annis.

(Fasti 6.771)

Time/The Fasti slips away and we age in the silent years.

Let us assure our contributors that Ramus will not slip away, its critical spirit will not age, nor will the years to come be silent. Non deficit.

AJB \& JLP 